\title{
補強コムの二軸延伸 $(\mathrm{I})$
}

\author{
(昭和47年12月27日 受理)
}

\section{戸谷 義弘* 杉 長俊* 瀬谷 弘旦*}

\begin{abstract}
要 旨 バルーン形等方二軸延伸装置を自作した。 これにより各種加硫ゴムの引張応力, 引張強さおよ び破断伸びを測定し，単純延伸のそれらと比較し下記の結果を得た。(1)純ゴムおよび非補強充てん剂の入っ た場合には，等方二軸延伸での引張応力の立ち上りは著しいが，カーボン・ブラック補強の場合は小さい. (2)等方二軸延伸では単純延伸に比べ，破断伸びや破断応力の配合による変化が少ない（3)等方二軸延伸のほ うがゴム相の性質を直接反映した破壊がおきやすいといえる. (4)単純延伸時よりも等方二軸延伸で高、引張 強さを示す場合ほど，引裂強さが小さい傾向がある。
\end{abstract}

1.はじめに

タイヤをはじめ多くのゴム製品は多軸変形を受けてい る場合が多い。しかしゴム試験法としては，単純引張を 与えたときの挙動の観察が主である.

最近，測定装置などの進歩もあり，加硫ニ゙ムの二軸変 形下での挙動の観察の報告がなされるようになってき だ．【かし今のところ，破壊に関しては純ゴム系を対 象としたものであり，補強系での研究はほとんど報告さ れていない。われわれは $\mathrm{Smith}^{2)}$ の装置を参考にしてバ ルーン形等方二軸試験機を自作し，補強ゴムの破壊挙動 の研究を行なっている.

本報では，装置の概要，実験方法，応力とひずみの算 出方法, および代表的加硫ゴムの測定結果などについて 報告する。

\section{2. 装置, 測定方法, 応力とひずみの算出方法}

\section{1 測定用試片の形状}

試片の形状を図 1 に示す.

周辺からの破壊が発生するのを防ぐために，周辺部は 中央部より厚くしてある。 またクランプしやすいよう に，周囲に縁がつけてある。試料はプレス・モールドに より作製し厚みはそのたびに測定する。

\section{2 測定装置および操作}

$\mathrm{Smith}^{2)}$ の装置を参考にして図 2 および図 3 に示す装 置を作製した，破壊実験は減圧弁 (1)により一次压 (2) を $5 \sim 6 \mathrm{~kg} / \mathrm{cm}^{2}$ （破壊圧より充分高くなっている）に設定 し, 一定に保って行なう. 次に試料の破壊までの時閒が

\footnotetext{
*日本ゼオン開発総合センター
}

（元 210 川崎市川崎区夜光 $1-2-1$ )
適当になるように，ガスの流速をニードルバルブ(13)で調 節する. スイッチ(3)をONにするとガスが流入し, 測定 が開始される．試料をふくらましている圧力を(15)で測定 する.

この装置は繰り返し二軸延伸疲労試験も行なえるよう に設計してある.プレッシャースイッチ16をを使用しての 圧力制御方式，タイマー(4)，(5)使用しての時間制御方 式が行なえるが，いずれの方法も定ひずみあるいは，定 応力の繰り返しとはならない，しかし前者は比較的，定 応力に近い測定を行なうことができる。この装置では速

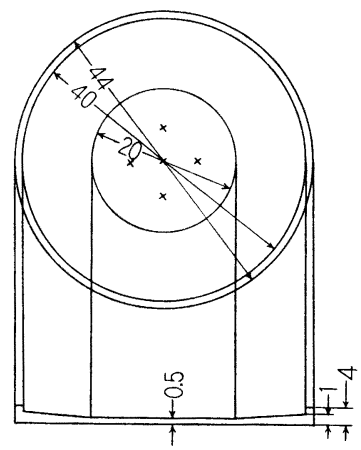

図 1 バルーン形延伸試片の形状

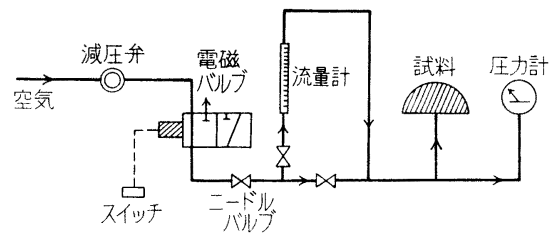

図 2 バルーン形二軸延伸機のブロックダイヤグラ ム 


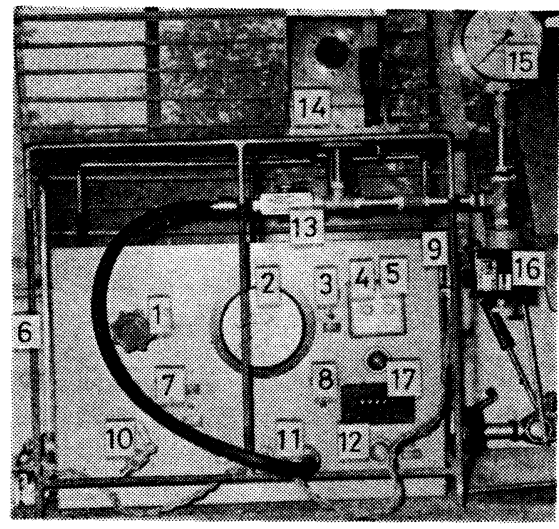

図 3 バルーン形二軸延伸機の完成図

1. 減圧弁 2.1 次圧ゲージ 3 . ガス供給スイ ッチ 4. ガス注入時間制御タイマー 5. ガス流 出時間制御タイマー 6 . 温度計 7 . 切換スイッ 于 8. 切換スイッチ 9. 流量計 10 . 高圧ガス 供給口 11。ガス供給口 12.メインスイッチ 13 . ニードルバルブ 14. 測定試料取り付け部 15. 測 定圧ゲージ 16. プレッシャースイッチ 17. カウ ンター

度制御機構が備わっていないため, 変形速度を一定に保 つことはできない，実験は速度範因を 10 40\%/sec の範 囲で行なった。 この速度範囲はJIS 3 号ダンベルを使用 した場合に換算すると，約 $100 \mathrm{~mm} / \mathrm{min} \sim 500 \mathrm{~mm} / \mathrm{min}$ の範囲となる。

\section{3 実験方法}

図 1 のメ点部に約 $0.5 \mathrm{~mm}$ 角のビニールテープをつけ た試料をクランプする. ビニールテープは膜面方向の伸 びを求めるためにはりつけるものである. 次に伸長前の 写真をスケールと一緒に撮影する。 スケールは図 4 の形 をしていて，試料のふくらみとともに変化する写真倍率 を決定するために必要である。次に 6 本の㸚じにより均

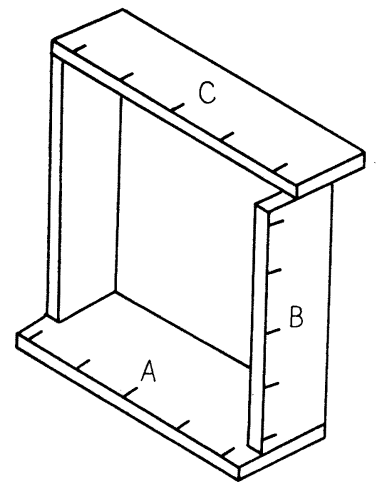

図 4 写真倍率決定のためのスケール
一に試料を固定し，ガスを送入する．この操作と同時に ストップウォッチを押し， $3 \sim 5$ 秒間隔 (手動式シャッ ターを使用しているため 3 秒以下は不正確となる) で破 断するまでの間に10２0枚写真を撮影する，写真はふく らんだ試料の側面, 平面，スケール，圧力計の指示を同 時に撮影する。 また破断と同時にストップウォッチを止 め，破断時間を記録する。

2.4 引張応力・伸び曲線, 引張強さ, 破断伸びの算 出方法

バルーン面に垂直な断面の平行方向への応力は次式で 表わされる3゙.

$$
\sigma=P R \alpha / 2 d_{0}
$$

ここで,

$$
\begin{aligned}
& \sigma: \text { バルーン面に垂直な断面の心力 } \\
& P: \text { バルーン内外の圧力差: } \\
& R: \text { バルーンの球面半径 } \\
& \alpha: \text { バルーンの面方向の伸長比 } \\
& d o: \text { バルーンの伸長前の厚さ }
\end{aligned}
$$

したがって 2.3 で述べた写真から， $P, R, \alpha$ (バルーン 面のビニールテープ間距離から求める) を読み取り, 式 (1)より応力が求められる. 何枚かの写真から，引張応力 一一伸び曲線を求めた。 また引張強さと破断伸びは，引張 応力ー時間および伸び-時間曲線を破断時間まで外捚して 求めた，特に $\alpha$ を求めるとき，写真上の距離を球面に之 った真の距離に換算する計算，掞よび試料のふくらみに よる写真倍率の変化の補正計算は，比較的複雑であるた め電子計算機を使用した。

\section{3. 測定装置の信頼性}

\section{1 ひずみの均一性の問題}

加硫ゴムをガス圧で膨張させると, 奏際は完全な球形 状を示さず，長円形状を示す，そこでひずみの均一性が 問題とされる. Treloar ${ }^{4)} の$ 詳細な研究を参考にして試料 表面各所にマークをつけて形状を調べた結果, 中心から $10 \mathrm{~mm}$ 以内でのひずみは均一とみなしても良いことが才 かった.

\section{2 破断位置}

破壊は，純ゴム加硫物を除いて，ほぼ中心付近で発生 していると思われる。図 5 に破断後の試料の形状のうち 典型的なものを示寸。

\section{3 大型バルーンと小型バルーンの引張応力-伸び曲 線の一致}

図 1 に示寸小形バルーン試料上外径 $200 \mathrm{~mm}$, 内径 100 $\mathrm{mm}$, 中心部厚さ $1 \mathrm{~mm}$ の大型バルーン試料の引張応力 


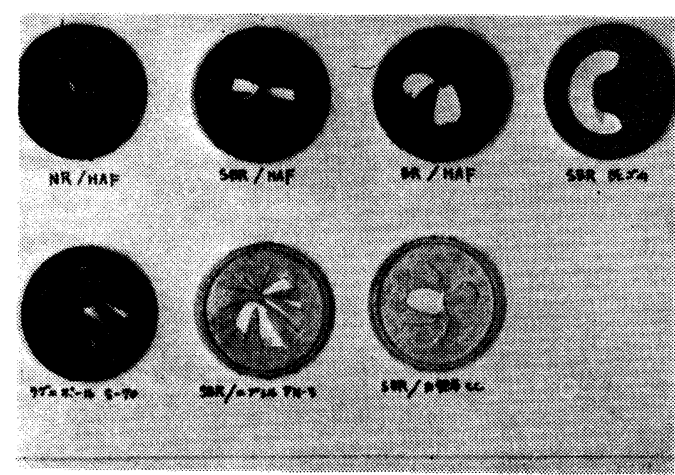

図 5 典型的な破断片の形状

一伸び曲線を図 6 に示す，両者はきわめて良い一致を示 していることがわかる．破断応力は大型の方がやや低い が，これは寸法效果によるものと考えてよかろう。

3.1，3.2，3.3 により自作装置の信頼性は良好である 上いえる.

\section{4 平均のとり方}

通常の引張試験と同じように，4枚の試片で実験を行 ない，JIS K 6301 に示される方法で平均を算出した.

一般にバルーン型試験では，単純延伸試験に比べ引張 強さ，破断伸びのばらつきは小さい.

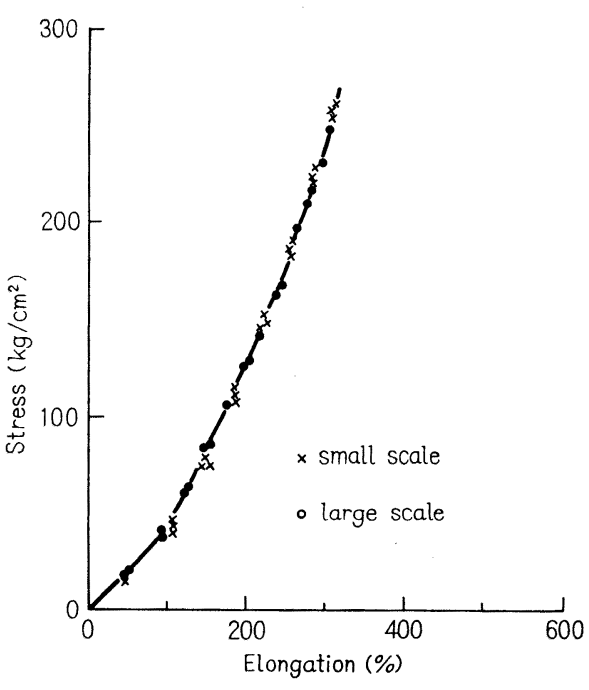

図 6 大型バルーンと小型バルーンの比較

\section{4. いくつかの加硫ゴムでの実験結果}

\section{1 試料および実験条件}

表 1 および表 2 に用いた試料の配合と加硫条件を示 す.試料は 6 インチ・ロールによって混練した.

単純延伸はJIS 3 号ダンベル，バルーン延伸は図 1

表 1 典型的な配合表

\begin{tabular}{|c|c|c|c|c|c|c|c|}
\hline & $\begin{array}{c}\text { SBR } \\
\text { GUM }\end{array}$ & $\begin{array}{l}\text { SBR } \\
\text { HAF }\end{array}$ & $\begin{array}{l}\text { NR } \\
\text { HAF }\end{array}$ & $\begin{array}{c}\text { BR } \\
\mathrm{HAF}\end{array}$ & $\begin{array}{c}\text { SBR } \\
\text { Hakuenka }\end{array}$ & $\begin{array}{c}\text { SBR } \\
\text { Nipsil }\end{array}$ & $\begin{array}{c}\text { Lignipol } \\
\text { S-70 }\end{array}$ \\
\hline SBR-1500 & 100 & 100 & & & 100 & 100 & \\
\hline RSS \#1 & & & 100 & & & & \\
\hline Nipol-1220 & & & & 100 & & & \\
\hline Lignipol S-70 & & & & & & & 170 \\
\hline $\mathrm{ZnO}$ & 3 & 3 & 3 & 3 & 5 & 5 & 5 \\
\hline $\mathrm{S}$ & 1 & 2 & 2.5 & 1.5 & 3 & 3 & 2.5 \\
\hline St. Acid & 2 & 2 & 2 & 2 & 1 & 1 & 1 \\
\hline Seast 3 & & 50 & 50 & 50 & & & \\
\hline Nipsil VN-3 & & & & & & 44 & \\
\hline Hakuenka CC & & & & & 60 & & \\
\hline $\mathrm{TiO}_{2}$ & & & & & 5 & 5 & \\
\hline $\begin{array}{l}\text { Fukkol M } \\
\text { D. E. G }\end{array}$ & & 5 & 5 & 5 & 2 & 2 & \\
\hline Acc. CZ & 1.5 & 1 & 1 & 1 & & & \\
\hline DM & & & & & 1.5 & 1.5 & 1.5 \\
\hline TS & & & & & 0.3 & 0.3 & \\
\hline TTCu & & & & & & & 0.45 \\
\hline Ant. PBNA & 1 & 1 & 1 & 1 & 1 & 1 & \\
\hline Ciure Time $150^{\circ} \mathrm{C}$ & $60^{\prime}$ & $60^{\prime}$ & $20^{\prime}$ & $30^{\prime}$ & $30^{\prime}$ & $75^{\prime}$ & $30^{\prime}$ \\
\hline
\end{tabular}


表 2 カーボン・ブラックの種類を変えた配合表

配合

SBR $1500 \quad 100$

酸化亜鉛 3

ステアリン酸

*1) アロマチックオイル 5

*2) ノクセラー $\mathrm{CZ} 1$

硫黄 2

カーボンブラック 変種

* 1) Fukkol-M

* 2) Cyclohexyl-benzotiazyl-Sulfenamide

加硫温度 $150^{\circ} \mathrm{C}$

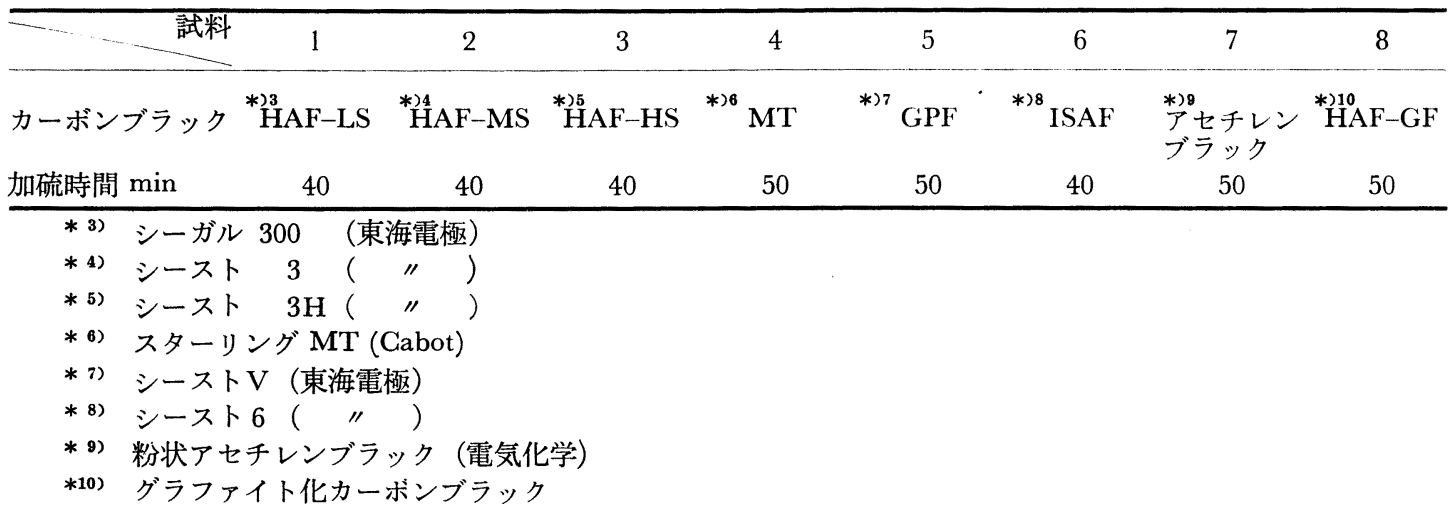

で示した試片を用いた，延伸速度は，単純延伸では 500 $\mathrm{mm} / \mathrm{min}(17 \% / \mathrm{sec})$, バルーン延伸では 10 30\%/sec で っあた. 測定温度は $25 \pm 2{ }^{\circ} \mathrm{C}$ あるる.

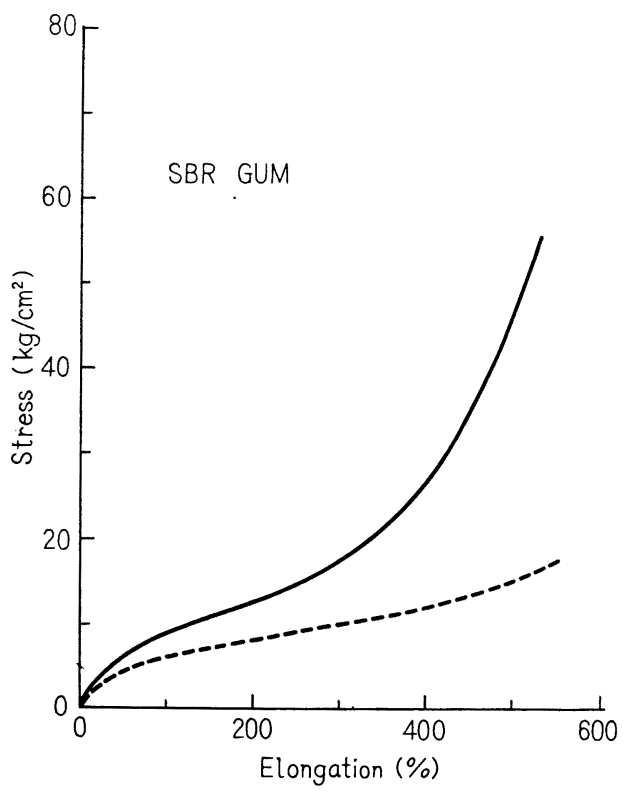

図 7 純ゴ ム SBR 加硫物の伸び一引張応力曲線, 点線は単純延伸, 実線は等方二軸延伸

\section{2 実験結果}

表 1 に示した純ゴム SBR, HAF 補強 SBR, 炭酸カル シウム補強 $\mathrm{SBR}$ の破断までの引張応力一伸び曲線を困 $7 ， 8 ， 9$ に示す。等方二軸延伸において，純ゴムおよ び弱補強の，大伸張時での引張応力の立ち上りは激しい

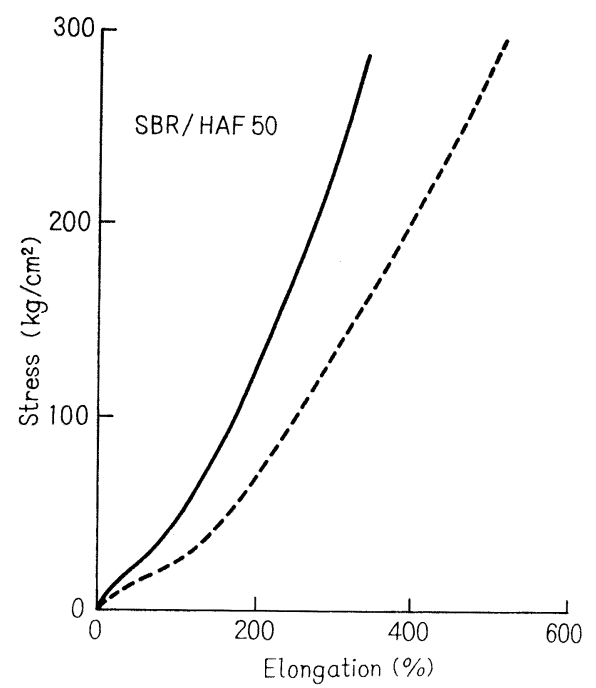

図 $8 \mathrm{HAF}$ カーボン50部補強 SBR の伸び一引張态 力, 点線は単純延伸，実線は等方二軸延伸 


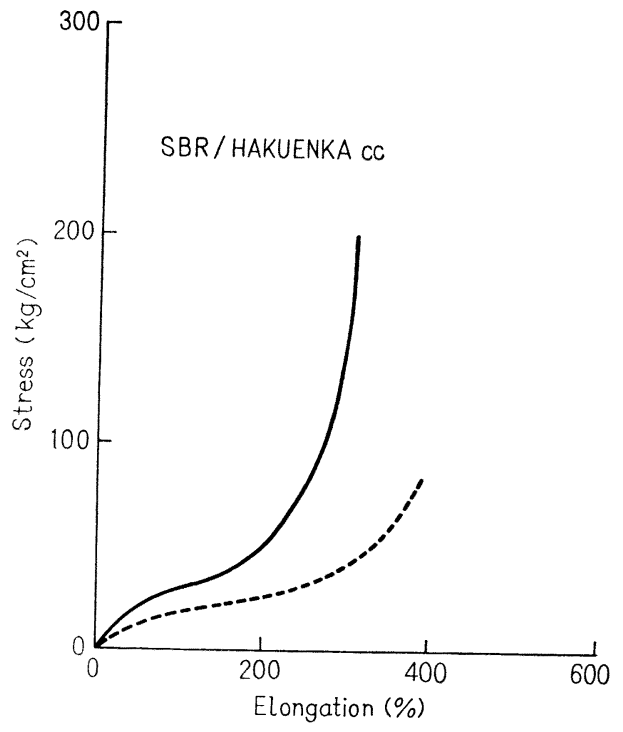

図 9 炭酸カルシウム，60部充てん SBR の伸び引張応力, 点線は単純延伸, 実線は等方二軸 延伸

が，強い補強性を示すカーボン・ブラック系の立ち上り は小さい，単純延伸でのゴム破断伸びと等方二軸延伸の それと比較すると，純ゴムではほぼ等しいが，粒子補強 系では明らかに後者は小さい，二つの延伸方法での引張

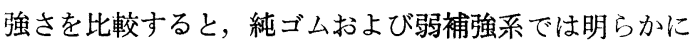
等方二軸延伸の方が大きい值を示すが，強い補強性粒子 を含む系では同等ないしは等方二軸延伸の方が低、。 れは破断時の真の応力で表示すると，より明らかである (表 3 ).

表 2 に示したカーボン・ブラックの種類を変えた加硫 物の引張強さおよび破断伸びをカーボン・ブラックの粒 径に対してプロットしたものが図10および図11である.

等方二軸延伸での両者のカーボン・ブラック粒径効果

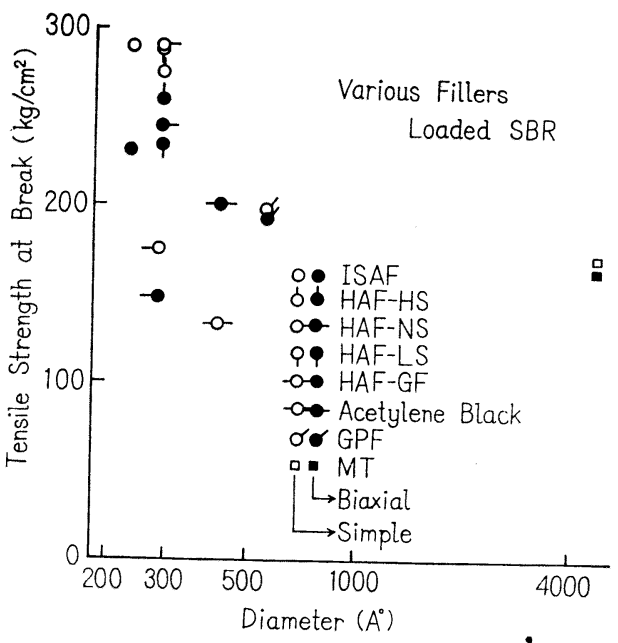

図10 カーボン・ブラックの粒径と引張り強さ

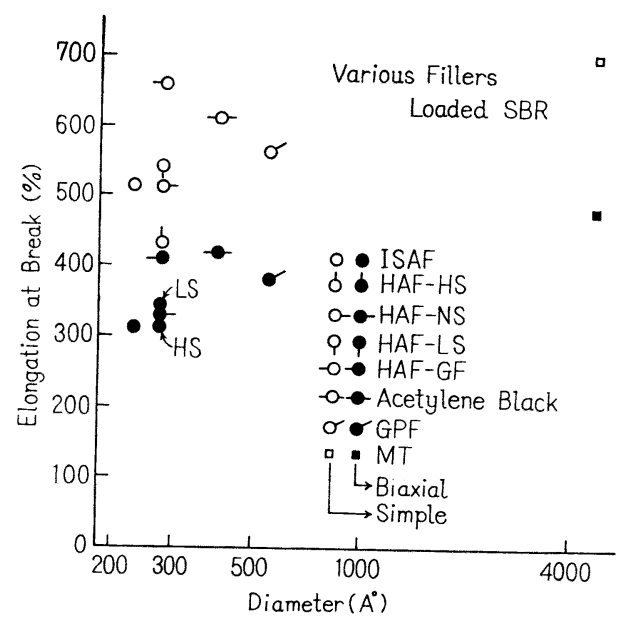

図11 カーボン・ブラックの粒径と破断伸び

表 3 延伸方法による引張強度の比較

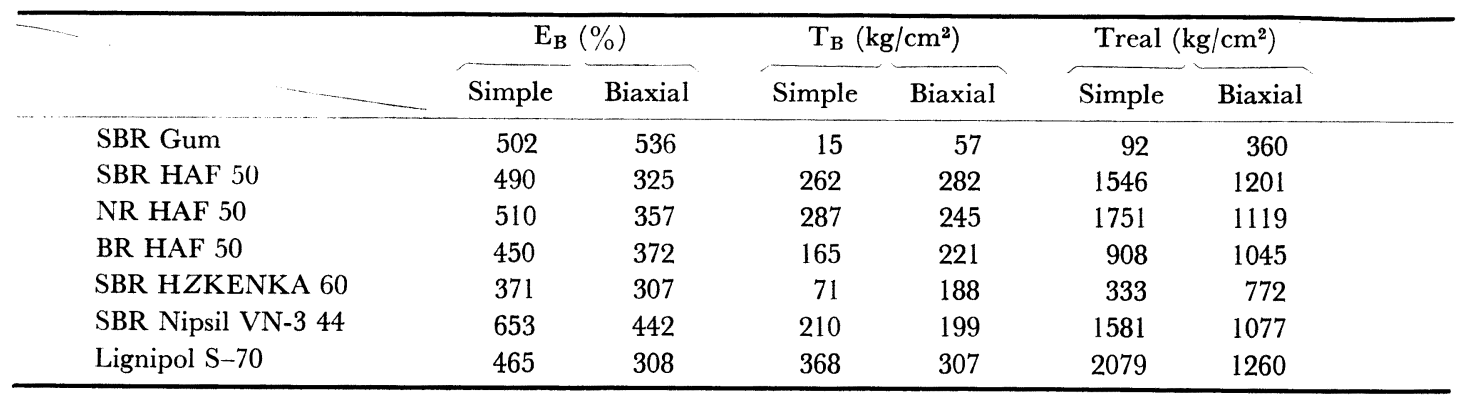


は，単純延伸のそれと本質的に同じ傾 向を示す。しか し, カーボン・ブラックのストラクチャーの影響は複雑 であり，引張強さに対するカーボン・ブラックのストラ クチャーの効果は, 単純延伸と等方二軸延伸では逆の傾 向がある.

一般に破断伸びは，等方二軸延伸では差が小さい．

\section{5. 考 察}

\section{1 引張応力}

等方二軸延伸のほうが単純延伸より高、引張応力を示 すことは，弾性論が示すところである。しかし図 7,8 9 に示されるように，補強剤の有無によって二つの延伸 方法の差は異なる。

川端ら ${ }^{1-a)}$ の報告によると等方二軸延伸でのひずみエ ネルギーのひずみインバリアント微分は，単純延伸での それらより小さい．われわれの実験は平衡応力の測定で はないから，単純延伸での引張応力一伸び曲 線より， Mooney-Rivlin ${ }^{5)}$ の式を用いて，等方二軸延伸での引張 応力を計算することは意味がない．しかし一つの目安と しての取り扱いをしてみると，明らかに実測の二軸応力 は計算値より高い.

これらの傾向はゴム鎖の均一変形を考えたのでは説明 がつかない，すでに筆者の一人の) は補強ゴムでは単純延 伸において局所的な変形がおきていることを報告してい る. 試片の変形と試片内部の変形の大きさの分布を, 与 えた変形の型（単純延伸，等方二軸延伸）に対し観察し ていくことが必要であろう。

\section{2 破断伸ひ}

表 1 亿示した試料の単純延伸抒よび等方二軸延伸での 破断伸びを対比させたものが図12である．図11および図 12より, 単純延伸に比べ等方二軸延伸では各試料間の破

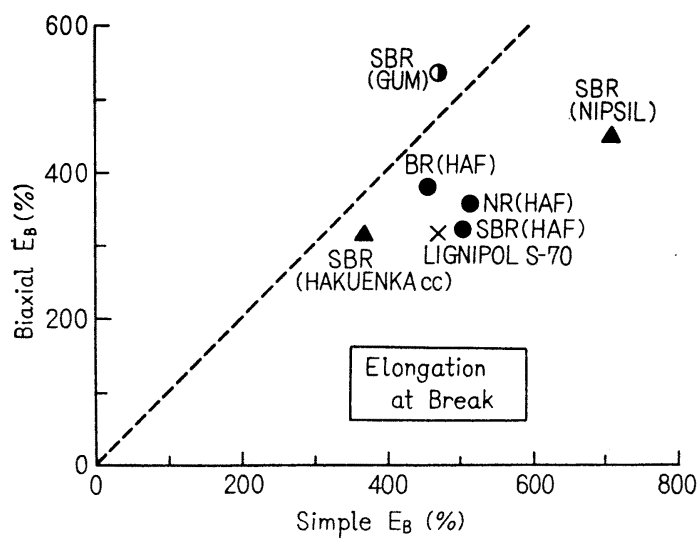

図12 単純延伸と等方二軸延伸での破断伸びの比較

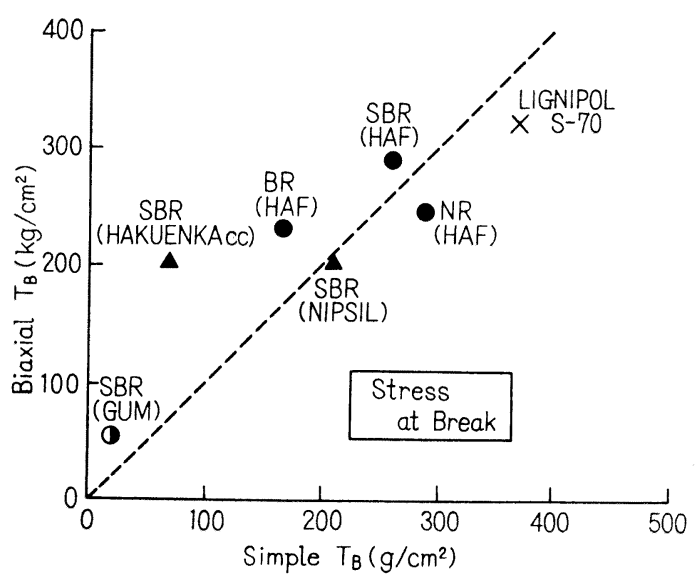

図13単純延伸と等方二軸延伸での引張強さの比較

断伸びの差が著しく縮まっていることがわかる、これ は，等方二軸延伸の方が，ゴム相の性質を直接反映する 傾向が強いことを示すものである.

\section{3 引張強さと引裂強さ}

図12に対応する単純延伸および等方二軸延伸での引張 強さを対比させたものが図13である。この図より一般に 引裂強さの弱いものは，単純延伸に比べ等方二軸延伸で の引張強さが大きい傾向にあることがわかる.Smith" が 指摘しているように，等方二軸延伸では応力集中，ある いはクラックの生長性のような引裂破壊に関係する破壊 機構が少ないことによるものであるう。

\section{引用 文 献}

1)-a 尾畑寛，川端季雄，河合弘迪：材料 19，330 (1970)

-b 臀原法, 川端季雄, 河合弘迪：材料 19，317 (1970)

2) T. L. Smith \& J. A. Rinde: J. Polymer Sci., $A-2$ 7687 (1969)

3) L. R. G. Treloar: Trans. Faraday Soc., 4059 (1944)

4) L. R. G. Treloar: Trans. IRI 19201 (1944)

5) L. R. G. Treloar: The Phes. Rubber Elasticity (Oxford 1949)

6) 戸谷義弘，寒河江静枝：日ゴム誌，46 1031 (1973) 
TENSILE PROPERTIES OF RUBBER VULCANIZATES UNDER BIAXIAL EXTENSION I.

\section{Yoshihiro Todani, Nagatoshi Sugi, Hirokatsu Seya(Nippon Zeon Co. Ltd., I-2-I, Ya- ko, Kawasaki-ku, Kawasaki-shi, 210 Japan)}

Using the balloon type extension apparatus, we determined the tensile stress, tensile strength and ultimate elongation of various kinds of vulcanizates under uniform biaxial extension for comparison with those under simple extension.

Whereas the tensile stress under uniform biaxial extension increased remarkably at large deformation in the cases of gum vulcanizates and non-reinforcing filler containing vulcanizates, that of carbon-black filled vulcanizates showed only a slight increase.

The differences of tensile strength or ultimate elongation between various vulcanizates are smaller under uniform biaxial extension than under simple extension. Then it may be said that a fracture directly reflecting the structure of rubber phase is more liable to happen under uniform biaxial extension.

We knew that the vulcanizates showing higher tensile strength under uniform biaxial extension than under simple extension exhibit lower tear strength.

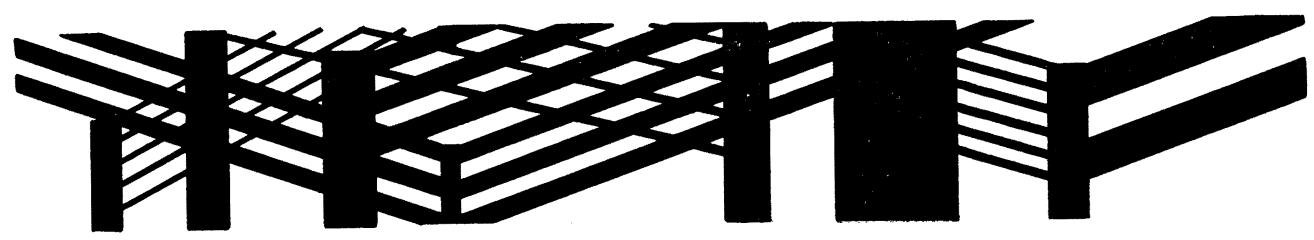

